Erratum to "Biological control for grapevine crown gall using nonpathogenic Rhizobium vitis strain ARK-1"

[Proc. Jpn. Acad., Ser. B 93, No. 8, 547-560]

By Akira Kawaguchi, Koji Inoue, Koji Tanina and Mizuho Nita

In this paper, the phrases should be corrected as follows:

(page 547, line 5)

For "Communicated by Satohiko SAKAKI, M.J.A."

Read "Communicated by Satohiko SASAKI, M.J.A." 


\title{
Review
}

\section{Biological control for grapevine crown gall using nonpathogenic Rhizobium vitis strain ARK-1}

\author{
By Akira Kawaguchi, ${ }^{* 1, \dagger}$ Koji Inoue, ${ }^{* 2}$ Koji Tanina ${ }^{* 2}$ and Mizuho NitA ${ }^{* 3}$ \\ (Communicated by Satohiko SASAKI, M.J.A.)
}

\begin{abstract}
Crown gall of grapevine, which is caused by tumorigenic Rhizobium vitis, is the most important bacterial disease of grapevine throughout the world. Screening tests of biological control agents resulted in the discovery of a nonpathogenic $R$. vitis strain ARK-1. By soaking grapevine roots with a cell suspension of strain ARK-1 prior to planting in the field, ARK-1 treatment significantly reduced the number of plants with crown gall symptoms. Several field trials result indicated that ARK-1 was very useful in the field, not only for grapevine but also for various other plant species. In experiments where a mixture of ARK-1 and a tumorigenic strain at a $1: 1$ cell ratio was examined in vitro and in planta, expression levels of the virulence genes virD2 and virE2 of the tumorigenic strain were significantly lower. The suppression of virulence genes, which can result in a reduction of gall formation and the pathogen population, seems to be a unique mechanism of ARK-1. These results indicated that ARK-1 is a promising new agent to control grapevine crown gall.
\end{abstract}

Keywords: Rhizobium vitis, grapevine crown gall, biological control, suppression of virulence genes

\section{Introduction}

Crown gall disease is one of the most economically important soil-borne bacterial plant diseases around the world. ${ }^{1)}$ Symptoms of crown gall are identified as hypertrophy (increase in size) and hyperplasia (increase in the number) of plant cells, which results in the formation of "galls" or tumors on roots and/or at the base or "crown" of woody plants such as pome fruit (e.g., apple, pear), stone fruit (e.g., cherry, apricot), and nut (e.g., almond, walnut) trees. ${ }^{1)}$ Abnormal cellular development is due to

*1 Western Region Agricultural Research Center, National Agriculture and Food Research Organization (NARO), Hiroshima, Japan.

*2 Research Institute for Agriculture, Okayama Prefectural Technology Center for Agriculture, Forestry and Fisheries, Okayama, Japan.

*3 AHS Jr. Agricultural Research and Extension Center, Department of Plant Pathology, Physiology, and Weed Science, Virginia Polytechnic Institute and State University, VA, U.S.A.

$\dagger$ Correspondence should be addressed: A. Kawaguchi, Western Region Agricultural Research Center, NARO, 6-12-1 Nishihukatsu-cho, Fukuyama, Hiroshima 721-8514, Japan (e-mail: kawaguchia240@affrc.go.jp).
DNA transfer from the crown gall pathogen into the plant. ${ }^{1)}$ The transferred bacterial DNA is incorporated into and expressed in the plant genome (Fig. 1), and it represents the only known example of DNA transfer from a bacterium to a plant in nature. ${ }^{1)}$ Other hosts of crown galls include ornamental woody crops such as roses, Marguerite daisies, and Chrysanthemum spp., as well as vines and canes such as grapevines and raspberries. ${ }^{1)}$ Occasionally, field crops such as cotton, sugar beets, tomatoes, beans, and alfalfa can develop crown galls, but the economic impact on these crops is not very high. ${ }^{1)}$

Grapevine crown gall, as one of the most important diseases of grapevine around the world, ${ }^{2), 3)}$ is caused mainly by Rhizobium vitis $(\mathrm{Ti})[=$ Agrobacterium vitis $(\mathrm{Ti})$, A. tumefaciens biovar 3], where "Ti" indicates "tumor-inducing" or "tumorigenic". Today, $R$. vitis $(\mathrm{Ti})$ is recognized as the predominant species causing grapevine crown gall. Based on reports over the past 30 years, the list of countries with grapevine crown gall includes China, Japan, South Africa, Chile, Israel, many countries in Europe, the Middle East, and many countries in North and South America. ${ }^{3)}$ Whereas in the majority of grape- 


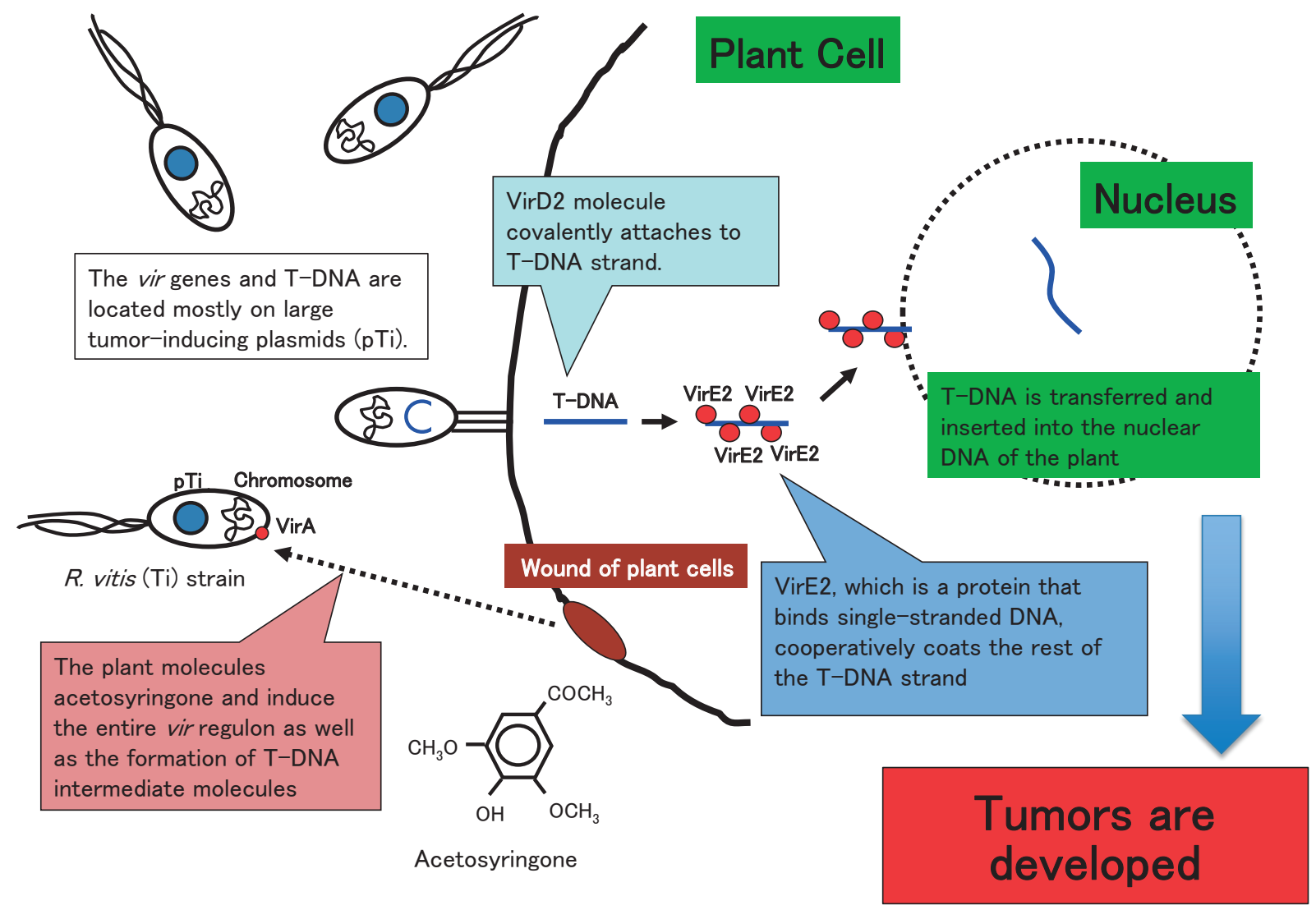

Fig. 1. The mechanism of crown gall disease in plant tissues. Infection of plants by Rhizobium is a multistage process. Virulent Rhizobium strains transfer single-stranded forms of T-DNA and several virulence effector proteins through a bacterial type IV secretion system into plant host cells.

growing regions, freezing injuries provide sites for initiating crown galls, in South Africa and Israel, high temperatures and humidity are considered equally important. Crown galls commonly form on the trunks and cordons of grapevines (Fig. 2a, b); however, symptoms can even develop on 1-year-old seedlings (Fig. 2c). Infected grapevines often produce inferior growth, and in some cases, the disease may cause partial or complete grapevine death (Fig. 2d).

Infection of plants by Rhizobium bacteria ( $\mathrm{Ti}$ ) is a multistage process. ${ }^{5)}$ Not all steps of the infection process for $R$. vitis have been identified, but known processes are very similar to those of $R$. radiobacter (Ti). The first steps are chemotactic attraction toward wounded plant cells (especially roots). Chemically attracted to wounds, $R$. vitis attaches itself to the underground portion of the grapevine. However, in the case of grapevines, wounding events such as freezing injuries are often associated with an outbreak of crown gall because exposed wounded tissues are more susceptible to infection by $R$. vitis. ${ }^{3)}$
Virulent Rhizobium Ti strains transfer singlestrand forms of T-DNA and several virulence effector proteins through a bacterial type IV secretion system into plant host cells. ${ }^{6,7)}$ Pathogenicity genes of Rhizobium $\mathrm{Ti}$ strains are mostly located on large tumor-inducing plasmids (pTi). A part of this plasmid (T-DNA) is transferred and inserted into the nuclear DNA of the plant during infection. ${ }^{4)}$ Subsequent expression of T-DNA genes results in the overproduction of auxins and cytokinins, which eventually leads to abnormal gall formation in the host plant. DNA genes then produce tumor-specific compounds called opines, which serve as nutrients for R. vitis. ${ }^{3)}$

Crown gall infection takes place not only in vineyards but also in nurseries. With nursery production, symptoms develop at the site of wounds made by disbudding, at the base of rooted cuttings, and at grafts; however, in many cases, the infected plants remain symptomless until frost or other physical damage initiates the disease. ${ }^{8)}$ Since nurseries 
are often located in places where the risk of frost is low, infected vines most likely do not develop obvious symptoms. Therefore, R. vitis is often transmitted through the vegetative propagation of infected asymptomatic grapevines. When mother vines at a nursery are infected, the pathogen can be spread very quickly through the production and dissemination of nursery stocks.

The most serious problems we face are that there are no effective control methods against grapevine crown gall. The nonpathogenic $R$. rhizogenes $[=A$. rhizogenes, A. radiobacter biovar 2] strain K84 has been used successfully to control crown gall in many plant species. ${ }^{9), 10)}$ An agrocin produced by K84 (agrocin 84), which is thought to be the primary factor in the control, ${ }^{11)}$ targets a tRNA synthetase in tumorigenic Rhizobium strains. ${ }^{12)}$ However, K84 does not prevent the initial infection of grapevine by R. vitis (Ti). ${ }^{3), 8), 13)-16)}$ Although several laboratories have attempted to develop other biological control agents for grapevine crown gall and reported some potential bacterial strains, they have not made a successful development until now.

Previously, we reported that some nonpathogenic R. vitis strains, which were isolated from grapevine nursery stock in Japan, inhibited tumor formation in some plant species including grapevine. ${ }^{13)-18)}$ In this review article, we focus on nonpathogenic $R$. vitis strain "ARK-1", which was identified in our lab and strongly inhibited tumor formation in grapevine in fields, as a new antagonistic strain.

\section{The crown gall problem casts a dark shadow over vineyards}

Grapes are an important agricultural product because they have a variety of uses, such as table grapes, wine production, juice production, or for drying into raisins. In particular, there is a great demand for wine production around the world, including the recent increase in popularity in the Japanese wine industry. A global examples that can be relevant to Japan is the State of Virginia, located in the mid-Atlantic region of the US. Although the history of wine grape production in Virginia started in 1860's when settlers from Europe brought grapevines to the New World, the modern Virginia wine industry did not start until the mid-1980's due to many disease and insect problems. ${ }^{19)}$ Currently, Virginia ranks fifth in wine grape production in the US, with 1,416 hectares of wine grape production (mainly Vitis vinifera, and inter- or intra-specific hybrids, and a very small production of $V$. labrusca) and over 260 wineries. $^{20)}$ After only three decades, the estimated annual economic income from the Virginia wine industry has reached $\$ 1.3$ billion (approximately 156 billion Japanese yen) in 2015 (new stats). With the Eastern part of Virginia facing the Atlantic Ocean and the Western part including the Appalachian Mountains, Virginia has a diverse range of climates. ${ }^{21)}$ Severe winter weather, as well as recent trends in extreme temperature fluctuations during late winter and early spring, tends to cause damage to grapevine trunks, which allows the entry of $R$. vitis. ${ }^{3)}$

Therefore, vine growers in Virginia, as well as in the other northern temperate climates, including Nagano and other northern prefectures in Japan, have been suffering from damage from crown gall on grapevines. In particular, the winters of 2013 and 2014 caused significant winter injury to grapevines in Virginia and many states north of Virginia, and many growers lost a considerable amount of grapevines due to crown gall. The level of damage was higher with less winter-hardy cultivars, such as Merlot and Tannat. For example, a 5-year-old Merlot vineyard located in the northern Virginia lost $100 \%$ of vines due to a combination of winter injury and crown gall (Nita, personal communication). Merlot is one of the most commonly grown wine grape cultivars in Japan. ${ }^{22)}$ The unpredictable weather patterns, lack of management strategies, and destructive nature of this disease have made crown gall one of the most difficult diseases for northern temperate climate viticulture.

\section{Screening tests for biological control agents}

3.1. Co-inoculation of plant stems with pathogens/nonpathogens. Results of a field survey of potential $R$. vitis (Ti) infections of mother plants and nursery stocks of grapevine in Okayama Prefecture, Japan, revealed that there were numerous nonpathogenic strains isolated on selective medium. ${ }^{13)}$ Most of these strains were identified as nonpathogenic $R$. vitis using pathogenicity tests, bacteriological characteristics, specific multiplex polymerase chain reaction (PCR), and $16 \mathrm{~S}$ rDNA sequencing analysis. ${ }^{13), 16)}$

Screening tests for biological control agents using nonpathogenic $R$. vitis by a needle-prick method were carried out, ${ }^{13), 14), 16)}$ with a total of 306 nonpathogenic strains to determine their activities against a pathogenic strain. Cell suspensions of the pathogenic and nonpathogenic strains were prepared 
and mixed in various combinations at cell ratios of $1: 1$. The inoculation consisted of a drop of the mixed cell suspension placed into a needle-prick wound on the stem of a tomato or grapevine seedling. We found that using tomato seedlings was appropriate in this screening test because tomato seedlings grow very fast from seeds and tumors formed easily on the stems by inoculation with $\mathrm{Ti}$ (tumorigenic) strains. ${ }^{13)}$ In a test with a $1: 1$ cell ratio of pathogen/ nonpathogen onto stems of tomato and grapevine, some strains greatly suppressed tumor incidence and the tumor size in stems compared to stems inoculated with only a pathogenic strain. Then, nonpathogenic R. vitis strains ARK-1, ARK-2, ARK-3, and VAR031 were selected as biological control agents against grapevine crown gall. ${ }^{16)}$

There are at least five genotypes in $R$. vitis $(\mathrm{Ti})$ based on multilocus sequencing analysis of housekeeping genes $\operatorname{pyr} G, \operatorname{rec} A$, and $r p o D{ }^{23)}$ On grapevine seedlings, a $1: 1$ cell ratio of each strain ARK-1, ARK-2, ARK-3, or VAR03-1 to the mixture of seven different $R$. vitis ( $\mathrm{Ti}$ ) strains belonging to five different genotypes, which were isolated from Japan, Australia, and Greece, significantly suppressed tumor incidence in stems. Among these, strain ARK-1 was found to be the strongest among the strains tested for inhibiting tumor formation. ARK-1 reduced tumor formation by an average of $90.6 \%$ of the positive control, which was the occurrence of tumor formation after inoculating with the pathogenic strain alone (Fig. 3, 4). So far, there have been no reports other than ours that any antagonistic strains strongly inhibited tumor formation on tomato and grapevine, as ARK-1 did using the needle prick inoculation at a $1: 1$ cell ratio. ARK-1 is a promising new agent to control grapevine crown gall.

Nonpathogenic $R$. rhizogenes strain K84, which was known as a nonantagonistic strain for control grapevine crown gall, was not able to inhibit tumor formation on grapevine shoots (Fig. 4). ${ }^{2), 13)-16)}$ In addition, a nonpathogenic $R$. vitis strain VAR06-30 was not able to inhibit tumor formation (Fig. 4) and was not an antagonist for grapevine crown gall. ${ }^{27)} \mathrm{We}$ are interested to clarify the mechanism of control of ARK-1 and why ARK-1 is overwhelmingly powerful in suppressing tumor formation compared with K84 and VAR06-30, and we discuss it in a later section.

3.2. Biological control by a root dipping method. R. vitis (Ti) usually infects plants from the soil into wounded roots. Pruned grapevine roots were soaked for $1 \mathrm{~h}$ in a cell suspension $\left(10^{8}\right.$ cells $\left./ \mathrm{ml}\right)$ of nonpathogenic strains ARK-1, ARK-2, ARK-3, or
VAR03-1. After soaking, treated grapevine seedlings were planted in pots with soil infested with a mixture of seven $R$. vitis ( $\mathrm{Ti}$ ) strains at a final concentration of $5 \times 10^{7}$ cells/g soil and grown in greenhouses. ${ }^{14)-16)}$ We carried out four experiments. Tumors formed on roots and a stem were studied. Treatment of grapevine roots with strains ARK-1, ARK-2, ARK-3, or VAR03-1 significantly reduced the percentage of grapevine seedlings with tumors caused by the $\mathrm{Ti}$ strains. ${ }^{14)-16)}$ Treatment using ARK-1 showed the highest control effect and reduced the incidence of galled plants by an average $85.2 \%$ of those on nontreated grapevine seedlings. ${ }^{16)}$ Thus, we verified that pre-inoculation of grapevine roots with ARK-1 was effective in reducing the percentage of plants with galls. These positive results encouraged us to conduct field trials on the assumption of the practical agricultural condition.

\section{Field trials for practical use}

Field trials are an essential part of the development of new agricultural technology. Field trials are especially important in developing biological control agents. Even though good results may be produced in laboratory experiments, field trials often do not show the expected results. Thus, we conducted field trials to verify the control effect of strain ARK-1 by root dipping method with nursery stocks of grapevine in several vineyards in Japan.

From 2009 to 2013, nine field trials designed as randomized or systematic controlled trials of biological control for grapevine crown gall were carried out at three different experimental fields (A to C) in Okayama, Japan. All field trials used nursery stock of grapevine (Vitis vinifera $\times V$. labrusca cv. Pione, or $V$. vinifera cv. Neo Muscat). The experimental fields were artificially infected with seven typical strains of R. vitis (Ti) belonging to five different genotypes. ${ }^{23)}$ Roots of plants were soaked for $1 \mathrm{~h}$ in a cell suspension of strain ARK-1 $\left(10^{8}\right.$ cells $\left./ \mathrm{ml}\right)$ or water, and were then planted in each plot. The arrangement of each plot was random or systematic within each field. Tumor formation on roots and stems of plants was investigated after 6-9 months.

The disease incidences in the nine field trials were subjected to meta-analysis according to a random effects model using the "DerSimonian-Laird method", because the field trials were performed with different plots sizes, numbers of plots, and plants, farms, and years. Meta-analysis is a set of statistical procedures for synthesizing research results from a number of different studies, and the DerSimonian- 


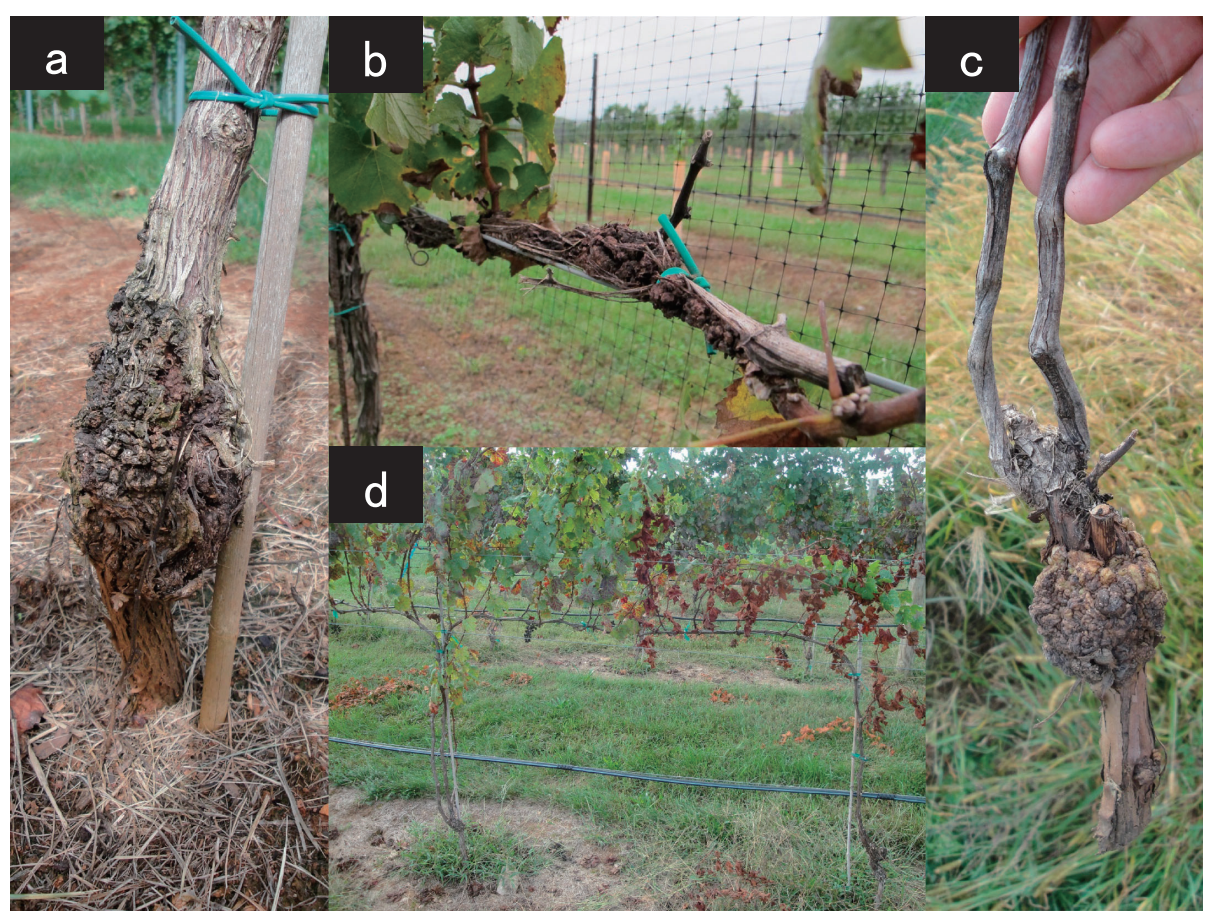

Fig. 2. The typical symptoms of grapevine crown gall: (a) Tumors commonly form on the trunks of grapevines; (b) Tumors commonly form on the shoots of grapevine; (c) Tumors even develop on 1-year-old seedlings; and (d) Infested grapevines often produce inferior growth, are inclined to drop leaves, and disease may cause partial or complete grapevine death.

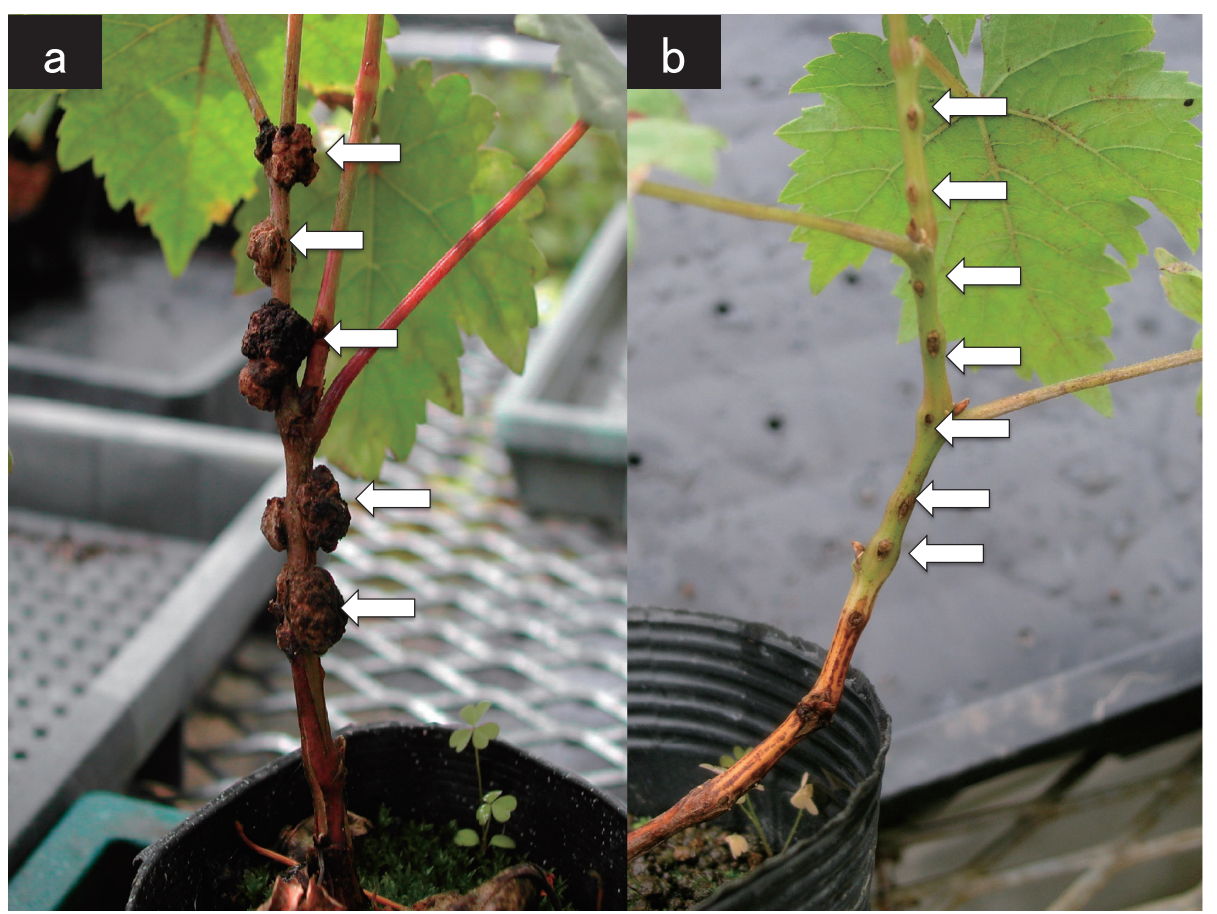

Fig. 3. Effect of strain ARK-1 on tumor formation. (a) A stem of grapevine was inoculated with mixtures of the R. vitis (Ti) strain as only pathogen. White arrows indicate tumors forming at the inoculation wound site (b) A stem of grapevine was inoculated with mixtures of $R$. vitis (Ti) strain and ARK-1 at the same time, but at a $1: 1$ cell ratio. White arrows indicate no tumors formation on inoculation wound site. The photograph was taken approximately 3 months after inoculation. 
Laird method can incorporate variations among studies. ${ }^{24)}$ An estimate of a statistical effect, such as the difference in disease severity for plants with or without treatment, is collected from each study along with a measure of the variance of the estimate of the effect. The effect size of antagonist treatment was calculated as an integrated risk ratio. The risk ratio was defined as Risk ratio $=$ (proportion of plants with tumors in antagonist treatment)/(proportion of plants with tumors in water treatment).

As shown in Fig. 5, the integrated relative risk was 0.18 (95\% confidence interval: $0.10-0.32, p<$

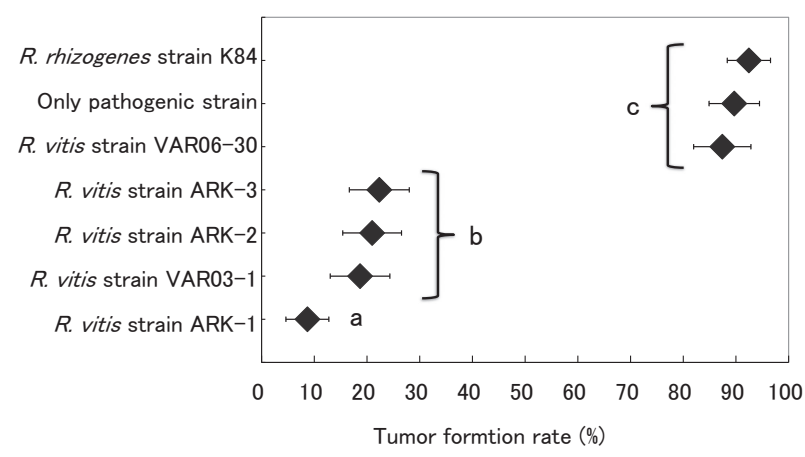

Fig. 4. Effect of co-inoculation with nonpathogenic Rhizobium strains and Ti strain at a $1: 1$ cell ratio on grapevine seedlings. Data are the means from three experiments. Error bars indicate 95\% confidential intervals. Rhombi labeled with different letters indicate a significant difference from the other bars $(P<0.05$, Ryan's multiple test).
0.001), indicating that ARK-1 treatment significantly reduced the disease incidence. The integrated relative risk value of 0.18 indicated that the incidence of crown gall disease during treatment with ARK-1 was decreased to $18 \%$ of that without ARK-1, demonstrating that the control effect was very high in the fields. Thus, the integrated relative risk value of 0.18 indicated that ARK-1 very useful in the field. The heterogeneity between each study was tested in a meta-analysis of the inhibitory effects of ARK-1. The I-squared, tau-squared, and $p$-values were 0,0 , and 0.97 , respectively, indicating that heterogeneity did not exist between field trials and that the integrated relative risk was mainly derived from the inhibiting effect of ARK-1. There are no reports of a biological control agent that is better than ARK-1 for inhibiting tumor formation on the grapevines in the field.

Meta-analysis of the seven field trials showed strong evidence that ARK-1 was effective in controlling grapevine crown gall by application in the field. The results indicated that soaking for 1 hour in a cell suspension of $10^{8}$ cells $/ \mathrm{ml}$ of ARK-1 was suitable for practical use. The effectiveness of ARK in controlling crown gall at a low cell density was advantageous in developing ARK-1 as a biopesticide. At present, we verified that $5 \times 10^{7}$ cells $/ \mathrm{ml}$ of ARK-1 gave a positive effect with a relative risk value $0.15(95 \%$ confidence interval: $0.03-0.27, p<0.05)$ on inhibition of gall formation in some field trials.

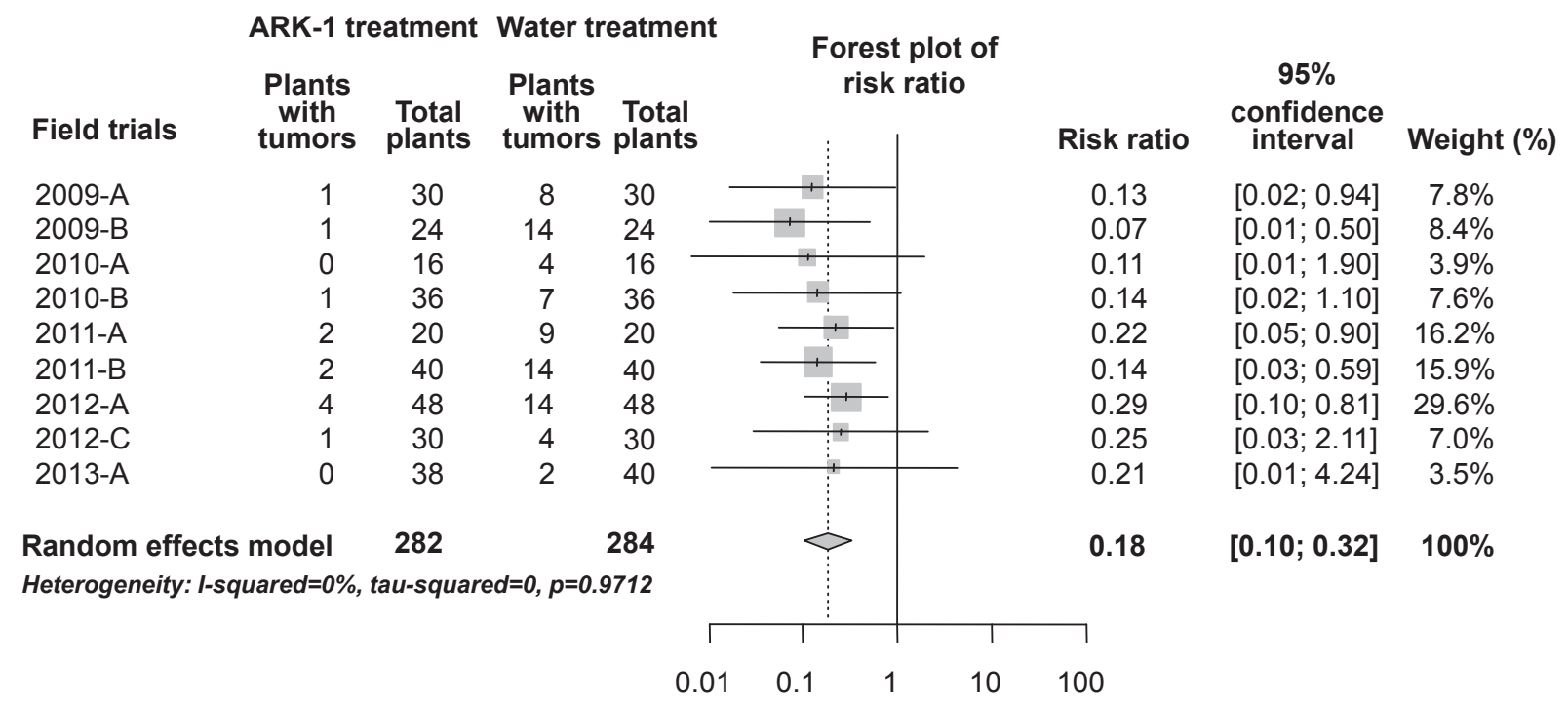

Fig. 5. Integrated evaluation based on a meta-analysis of the effect of nonpathogenic $R$. vitis strains ARK-1 on grapevine crown gall after soaking plant roots in bacterial cell suspensions in field trials. The center and width of the diamond shape demonstrate the value of the integrated relative risk and $95 \%$ confidence interval, respectively. 
In addition to grapevines, we have evidence that ARK-1 can effectively control apple, Japanese pear, peach, rose, and tomato crown gall caused by $R$. radiobacter $(\mathrm{Ti})$ and $R$. rhizogenes $(\mathrm{Ti})$ strains, based on four fields and three greenhouse trials. ${ }^{18)}$ Therefore, ARK-1 effectively protects six different species (grapevine, apple, Japanese pear, peach, rose, and tomato) of host plants against three different Rhizobium Ti strain species (R. radiobacter (Ti), $R$. rhizogenes $(\mathrm{Ti})$, and $R$. vitis $(\mathrm{Ti}))$.

\section{Population dynamics of ARK-1 on roots of grapevine}

In order to determine the rate of ARK-1 survival on grapevine roots in the soil, an antibiotic-resistant mutant of ARK-1, ARK-1sc, was developed. ARK1sc was a streptomycin (St)-copper sulfate $\left(\mathrm{CuSO}_{4}\right)$ resistant mutant (St-CuSO 4 -mutant) obtained by growing strain ARK-1 on a special culture medium with $\mathrm{St}$ and $\mathrm{CuSO}_{4}$ named "St-CuSO${ }_{4}$ Potato Sucrose Agar (PSA) medium". 25),26) The ARK-1sc strain was inoculated onto roots using the root dipping method, and at 1-, 6-, 18-, 24-, 30-, and 36-month after inoculation, the colony forming units (CFU) of ARK1sc were counted on $\mathrm{St}_{-} \mathrm{CuSO}_{4}$-PSA media. As shown in Fig. 6, 12 months after inoculation with strain ARK-1sc, the bacterial population inside roots was $2 \times 10^{6} \mathrm{CFU} / \mathrm{g}$ (fresh weight) of the root. Colonization by ARK-1sc inside roots remained at $5 \times$ $10^{4} \mathrm{CFU} / \mathrm{g}$ of the root for up to 24 months, and then dropped to $6 \times 10^{3} \mathrm{CFU} / \mathrm{g}$ of root after 36 months.

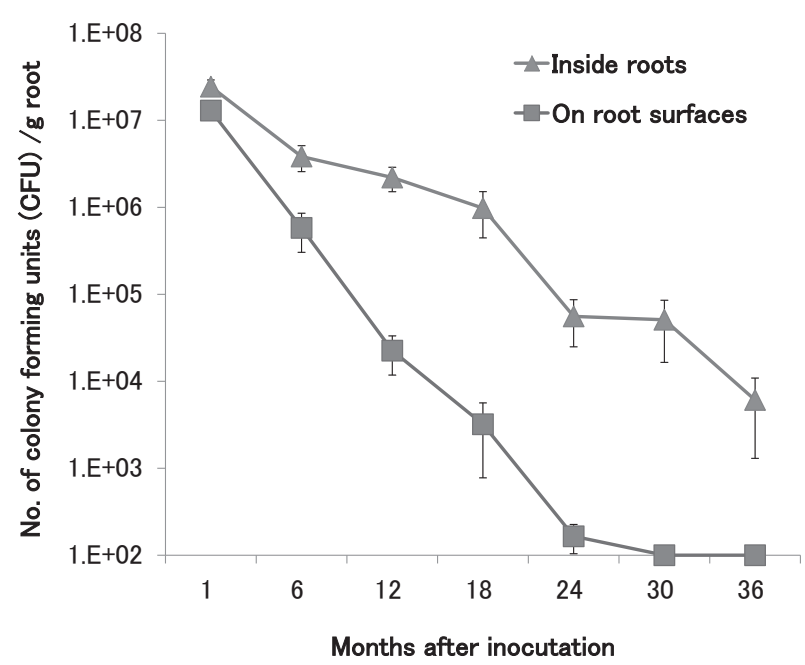

Fig. 6. Population dynamics of nonpathogenic R. vitis strain ARK-1sc in the roots of grapevine after inoculation. Data are the means of eight rootstocks. Error bars represent the standard error of the mean.
On the other hand, at 12 months after inoculation with strain ARK-1sc, the bacterial population on the root surfaces was $2 \times 10^{4} \mathrm{CFU} / \mathrm{g}$ of the root. Colonization by ARK-1sc on root surfaces decreased to $2 \times 10^{2} \mathrm{CFU} / \mathrm{g}$ of root after 24 months, and after 30 months, ARK-1sc was not detected on root surfaces.

Thus, the result for ARK-1sc indicated that strain ARK-1 not only established populations in the rhizosphere of grapevine but also persisted inside roots for up to 3 years. On the other hand, colonization of ARK-1sc on root surfaces decreased to the detection limit after 30 months. These comparisons of ARK-1sc survival inside roots and on roots surfaces demonstrated that the bacterial population on root surfaces was always lower than that inside the roots. ARK-1 was originally isolated from internal tissues of grapevine, ${ }^{13)}$ indicating that ARK-1 is an endophytic bacterium. This phenomenon needs further investigation because the ability of ARK-1 to colonize grapevine roots might affect the persistence of the control of crown gall by ARK-1. It is also important to determine in which grapevine tissue ARK-1 colonizes. This can be investigated by visualizing bacterial colonization patterns with the use of a luminous protein (e.g., green fluorescent protein).

\section{Understanding the mechanism of strain ARK-1}

6.1. Need live-cells of ARK-1. In order to understand the mechanism of the biological effects of ARK-1, an inoculation study was conducted with three different forms of ARK-1: a cell suspension of ARK-1 as "live cells"; a cell suspension of ARK-1 autoclaved at $121^{\circ} \mathrm{C}$ in 15 minutes as "dead cells"; and a culture filtrate of ARK-1 by filtering with a syringe filter unit $(0.2 \mu \mathrm{m}$ diameter $)$ as "culture filtrate $(\mathrm{CF})$ ". Each treatment consisted of a mixture of ARK-1 cells and an R. vitis (Ti) (tumorigenic) strain cells at $1: 1$ ratios, and these were inoculated onto stems of grapevine seedlings using the needleprick methods described above. ${ }^{13), 14), 16)}$

Results showed that the live strain ARK-1 in a cell suspension significantly suppressed tumor incidence in stems compared to the control treatment using Ti strains (protective value $=89.1 \%$ ). ${ }^{16}$ On the other hand, the dead cells and CF suspension did not reduce tumor incidence (both protective values $=$ $6.4 \%){ }^{16)}$ Basically, the mechanism of antagonistic microorganisms as biological control agents for plant disease involves bacteriocins or antibacterial materials. However, the lack of control by dead cells 
and CF suspension indicated a different mechanisms for ARK-1 and that ARK-1 may have cellular functions to control crown gall formation.

6.2. Reducing the pathogen population at the wound site. A survival assay of ARK-1 was conducted. To differentiate the inoculated biological control agents from indigenous rhizobacteria, $R$. vitis strains used in the experiment consisted of three antibiotic-resistant mutant strains, ARK-1sc, VAR06-30sc, and VAT03-9n. ARK-1sc, as described above, is an $\mathrm{St}_{-\mathrm{CuSO}}$ mutant obtained by growing ARK-1 on St-CuSO${ }_{4}$-PSA medium. ${ }^{25), 26)}$ Nonpathogenic $R$. vitis strain VAR06-30 was a nonantagonistic strain that was not able to inhibit tumor formation (Fig. 4), and a St-CuSO 4 mutant obtained by growing VAR06-30 on St-CuSO 4 -PSA medium was called VAR06-30sc. ${ }^{27}$ R. vitis (Ti) strain VAT03-9 was a tumorigenic strain isolated from grapevine, ${ }^{13)}$ and VAT03-9n was a nalidixic acid (nal)-resistant mutant (nal-mutant) obtained by growing on nal-PSA medium. ${ }^{27)}$ The three mutants grew on the $\mathrm{St}_{-\mathrm{CuSO}}$-PSA medium (ARK-1sc and VAR06-30sc) and the nal-PSA medium (VAT03-9n) at rates similar to the wild-type in PSA medium. ${ }^{27}$ Inoculation to grapevine seedlings took place with one of three different cell suspensions: 1) ARK-1sc and VAT03-9n (1: 1 ratio); and 2) VAR06-30sc and VAT03-9n (1 : 1 ratio). Additional experimental runs consisted of grapevine seedlings inoculated with the each cell suspension of ARK-1sc, VAR06-30sc, or VAT03-9n to demonstrate the population dynamics with single strain inoculation.

Populations of ARK-1sc on the plants resulted in significantly higher number $(P<0.05)$ than those of VAT03-9n at 7 and 9 days after inoculation (dai) (Fig. 7a). On the other hand, populations of VAR0630sc and VAT03-9n did not significantly differ in numbers up to 9 dai (Fig. 7b). Single inoculation of ARK-1sc, VAR06-30sc, and VAT03-9n did not result in a significant difference in population level even after 9 dai (Fig. 7c). These results suggested that ARK-1sc could not reduce the pathogen population at the wound site on the grapevine plants during the early period after infection, but after 7 dai, suppressed the population of VAT03-9n. The other result was obtained that colonization by ARK-1sc remained roughly constant at $4 \times 10^{7} \mathrm{CFU} / \mathrm{g}$ of grapevine shoot for up to 88 dai, but colonization by $\mathrm{Ti}$ strain decreased to $1 \times 10^{6} \mathrm{CFU}$ g- 1 of the grapevine shoot after 88 dai. ${ }^{26)}$ In the co-inoculation assay, the populations of $\mathrm{Ti}$ strain were approximately $10^{7} \mathrm{CFU} / \mathrm{g}$ in grapevine shoots with tumors and $10^{6} \mathrm{CFU} / \mathrm{g}$ in shoots without tumors. ${ }^{26)}$ These results demonstrated that $\mathrm{ARK}-1 \mathrm{sc}$ reduced the population of the tumorigenic bacterial population to significantly lower level by an order of ten-fold. Therefore, one of the mechanisms allowing the biological activity of ARK-1 is a significant inhibition of a population development of the Ti strain from 7 dai.

6.3. Suppressing the expression of essential virulence genes in the tumorigenic strain. Transformation of the host DNA by $R$. vitis would most likely to occur prior to 5 dai. ${ }^{28)}$ The suppression of gall formation with co-inoculation of ARK-1 and the Ti strain occurred even with a lack of suppression of the Ti strain population by ARK-1 until 5 dai (Fig. 7a). This result indicated that the mechanism by ARK-1 to reduce crown gall symptoms might not involve the suppression of the Ti strain population in grapevine plants.

The virulence (vir) genes and T-DNA are located mostly on $\mathrm{pTi}$ and chromosomal virulence genes $(c h v)$ on chromosomes. ${ }^{6), 7)}$ The plant molecules acetosyringone and $\alpha$-hydroxyacetosyringone induce the expression of the entire vir regulon in Rhizobium as well as the formation of T-DNA intermediate molecules. ${ }^{7)}$ These plant molecules occur specifically in the exudates from wounded and metabolically active plant cells, thus, they probably allow Rhizobium to recognize susceptible cells in nature. ${ }^{7)} \mathrm{T}$ DNA transfer and processing require products of the $\operatorname{vir}$ genes (virA, $\operatorname{vir} B, \operatorname{vir} C, \operatorname{vir} D, \operatorname{virE}$, and $\operatorname{vir} G)$, which are located outside of the T-DNA coding region. 6),7),29),30) The expressions of $\operatorname{vir} B, \operatorname{vir} C, \operatorname{vir} D$, and virE are positively regulated at the transcriptional level by plant signal molecules. ${ }^{6,7), 29)}$ Two tumorigenic Rhizobium proteins, VirD2 and VirE2, directly associate with the T-DNA strand; one VirD2 molecule covalently attaches to the 5 '-end of the TDNA strand, and VirE2, a protein that binds singlestranded DNA, cooperatively coats the rest of the TDNA strand (Fig. 1).6),7),29)

To provide insights into that mechanism, we investigated the effect of ARK-1 on suppressing the expression of two virulence genes, virD2 and virE2, by the $\mathrm{Ti}$ strain; this suppression appeared to be responsible for the biological control by ARK-1.

6.3.1. Suppressive effect of ARK-1 co-inoculation on the expression of the vir genes of the Ti strain. To clarify whether ARK-1 suppresses the expression of vir genes of $\mathrm{Ti}$ strain VAT03-9 in planta, the expression of virD2 and virE2 was analyzed in grapevine plants co-inoculated with ARK-1 and 

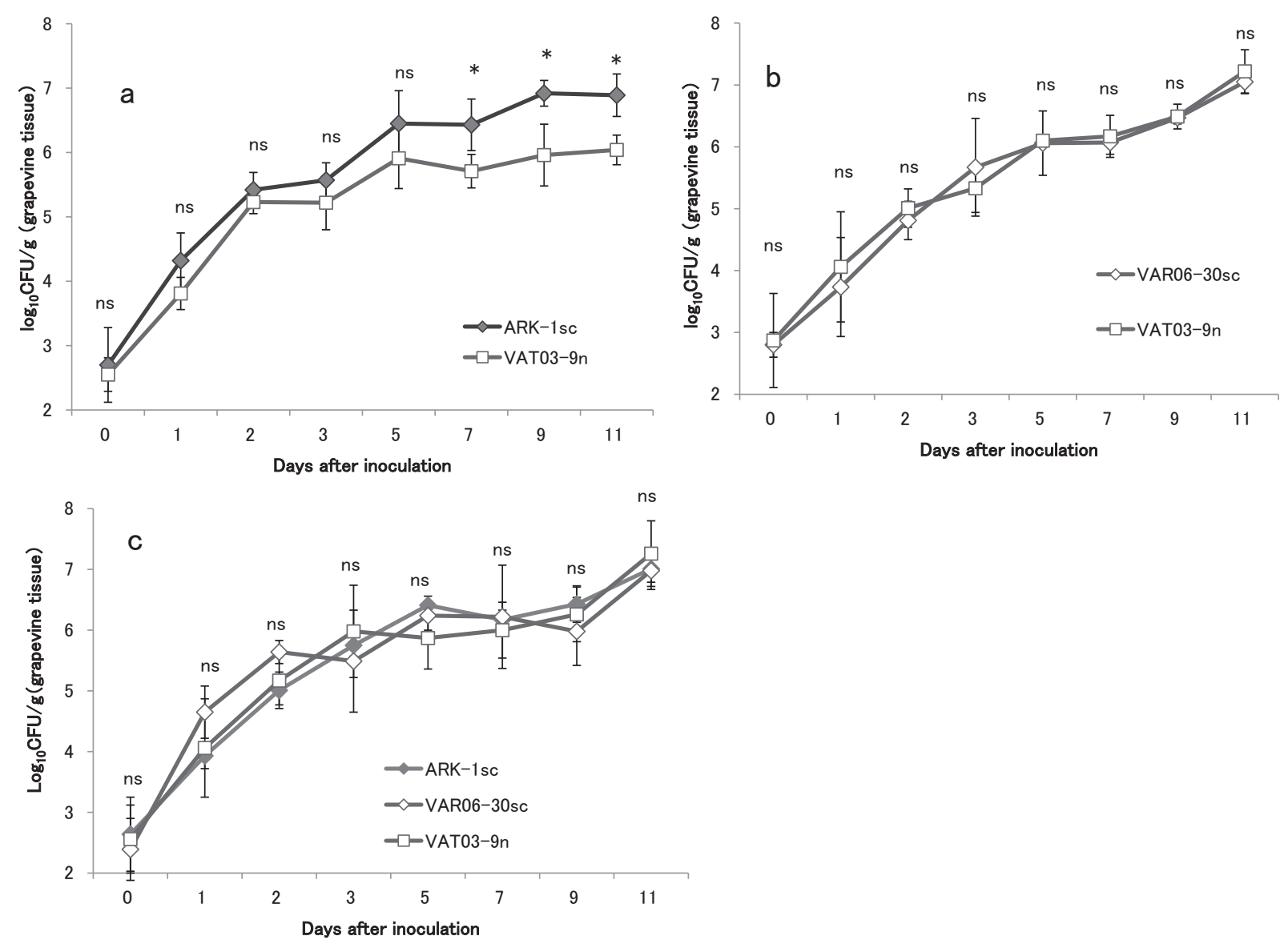

Fig. 7. Population dynamics of the nonpathogenic strains and VAT03-9n after co-inoculation onto grapevine plants. (a) Populations of the nonpathogenic strain ARK-1sc and of the tumorigenic (Ti) strain VAT03-9n after co-inoculation on wounded shoots of grapevine seedlings at a $1: 1$ cell ratio. (b) Populations of the nonpathogenic strain VAR06-30sc and of the Ti strain VAT03-9n after coinoculation on wounded shoots of grapevine seedlings at a 1:1 cell ratio. (c) Populations of the nonpathogenic strain ARK-1sc, of strain VAR06-30sc, and of the tumorigenic (Ti) strain VAT03-9n after each inoculation on wounded shoots of grapevine seedlings. Data are means \pm standard deviation for five plants. (a) and (b) Significant differences at a given point in time are indicated by * (t-test, ${ }^{*} P<0.05 ;{ }^{* *} P<0.01 ;{ }^{\text {ns }} P \geq 0.05$ ). (c) No significant differences at a given point in time are indicated by ns (Tukey's HSD test, $\left.{ }^{\text {ns }} P \geq 0.05\right)$. dai, days after inoculation.

VAT03-9. Shoots of grapevine seedlings were inoculated with nonpathogenic strains (ARK-1 or VAR0630) and Ti strain VAT03-9 at a cell ratio of $1: 1$, and CF of ARK-1 plus VAT03-9 by the needle-prick method as described above. Shoot samples containing one wound site were collected, and bacterial RNA was extracted. The amount of mRNA expression of virD2 and virE2 of the Ti strain were analyzed using a reverse-transcription quantitative polymerase chain reaction ( $\mathrm{RT}-\mathrm{qPCR})$.

In plants inoculated with only VAT03-9, the induction of bacterial virD2 and virE2 expression was detected at 1 dai (Fig. 8). No significant difference in the expression levels of virD2 and virE2 were observed upon co-inoculation with VAR06-30 or CF of ARK-1 and VAT03-9 in comparison with inoculation with only VAT03-9 (Fig. 8). On the other hand, virD2 and virE2 expression levels were significantly suppressed upon co-inoculation with ARK-1 and VAT03-9 (Fig. 8). These results suggested that treatment with ARK-1, which inhibited tumor formation, could suppress the expression of virD2 and virE2 by the Ti strain in grapevine plants. On the other hand, co-inoculation with VAR06-30 and $\mathrm{CF}$ of ARK-1 could not suppress the expression of these genes, hence, and they could not inhibit tumor formation.

To evaluate the starting and ending time points of the suppression of vir gene expression by ARK-1, virD2 expression was analyzed from 1 hour after 


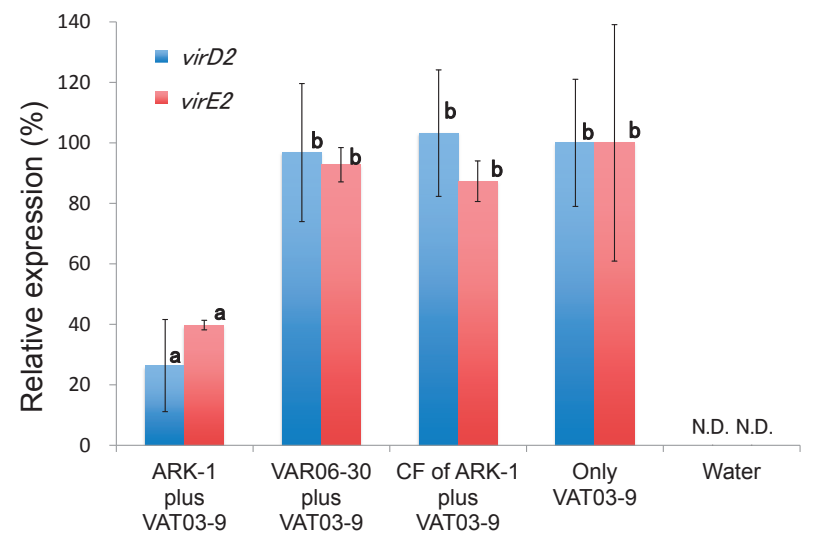

Fig. 8. Relative expression levels of the virD2 and virE2 genes in bacterial cells of the $R$. vitis $\mathrm{Ti}$ strain in grapevine plants measured using reverse-transcription quantitative polymerase chain reaction (RT-qPCR). Values (\%) represent the relative expression levels of the vir genes at 1 day after inoculation (dai) compared with the value when only Ti strain VAT03-9 was inoculated ("only VAT03-9"), which had a value of 100\%. Each cell suspension or mixture (ARK-1 plus VAT03-9, VAR06-30 plus VAT03-9, CF of ARK-1 plus VAT03-9, and only VAT03-9) at cell ratios of $1: 1$ was inoculated onto the stems of grapevine plants after wounding. Stem samples were harvested at 1 dai. Data are means \pm standard deviation for samples corresponding to individual plants. Bars labeled with different letters indicate a significant difference from the other bars $(P<0.01$, Tukey's HSD test). CF, culture filtrate. inoculation (hai) to 4 dai in grapevine plants coinoculated with ARK-1 and VAT03-9 (Fig. 9). The level of virD2 expression after an inoculation with VAT03-9 was significantly higher at 1 dai than at any other time (Fig. 9). The levels of virD2 expression were significantly lower with a coinoculation with ARK-1 and VAT03-9 than with a single inoculation of VAT03-9 at 12 hai, 1 dai, and 2 dai (Fig. 9). These results suggested that coinoculation with ARK-1 was able to suppress virD2 expression by the Ti strain in grapevine plants during the peak period of virD2 gene expression. However, the effect of ARK-1 became unclear at 3 and 4 dai because virD2 expression in plants inoculated with only the Ti strain (VAT03-9) was also low during this period.

6.3.2. Suppressive effect of ARK-1 co-inoculation on vir gene expression of Ti strain in culture media with or without acetosyringone. The kinetics of virD2 and virE2 expression were analyzed in culture media with or without acetosyringone to examine whether the suppression of the vir genes was indeed caused by ARK-1. Four cell suspensions (ARK-1 plus VAT039, VAR06-30 plus VAT03-9, and CF of ARK-1 plus VAT03-9 at cell ratios of $1: 1$, and only VAT03-9)

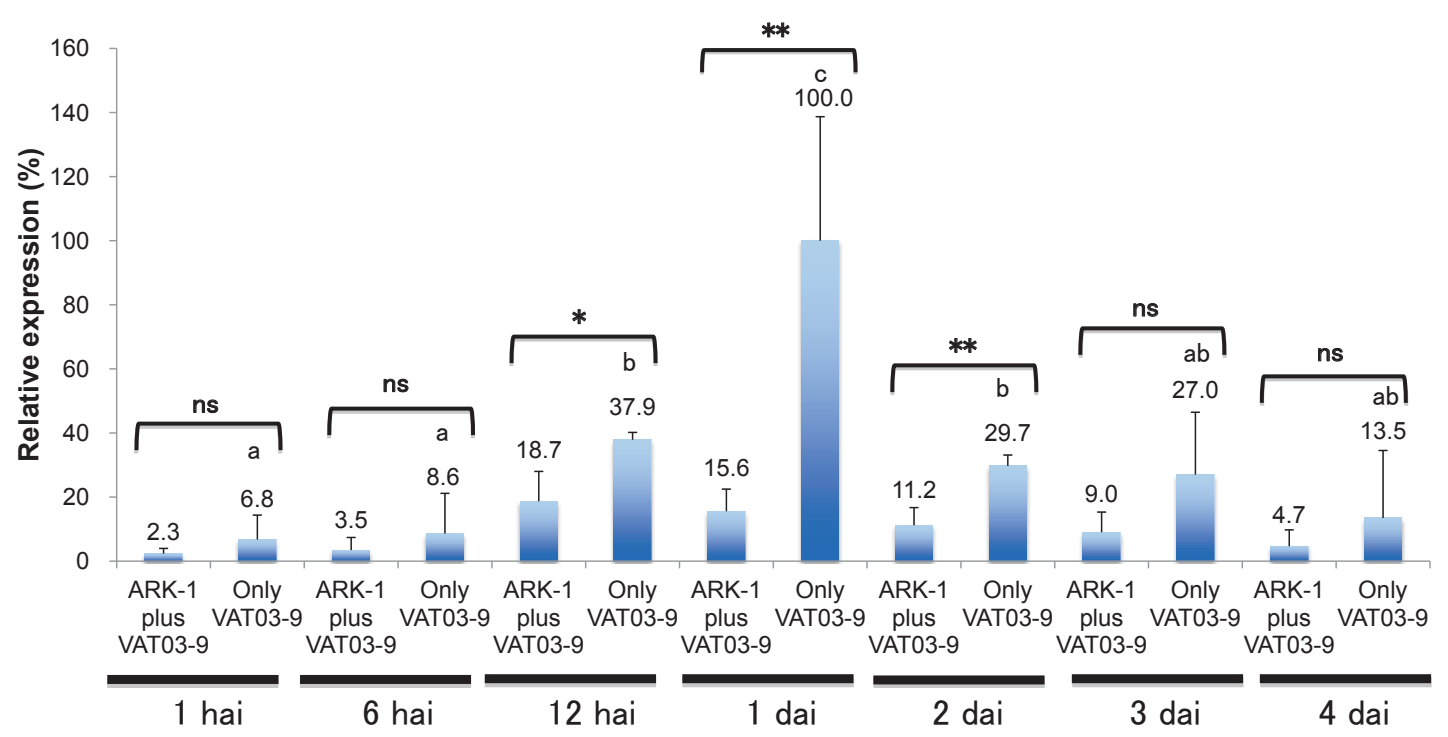

Fig. 9. Changes in the relative expression levels of the virD2 gene in grapevine plants measured using the reverse-transcription quantitative polymerase chain reaction (RT-qPCR). Values (\%) represent the relative expression levels of the vir genes at 1 day after inoculation (dai) compared with the value when only Ti strain VAT03-9 was inoculated ("only VAT03-9"), which had a value of $100 \%$. A mixed cell suspension of the nonpathogenic strain ARK-1 and of the Ti strain VAT03-9 at cell ratios of $1: 1$ or a single cell suspension of VAT03-9 were inoculated onto the stems of wounded grapevine plants. Stem samples were harvested at times ranging from 1 hour after inoculation (hai) to 4 dai. Data are means \pm standard deviation for samples corresponding to individual plants. Significant differences at a given point in time between the ARK-1 plus Ti mixture and only the Ti strain are indicated by * $(t$-test, $\left.{ }^{*} P<0.05 ;{ }^{* *} P<0.01 ;{ }^{\text {ns }} P \geq 0.05\right)$; bars for only the Ti strain that are labeled with different letters differ significantly from other bars for only the Ti strain (Tukey's HSD test, $P<0.05$ ). 


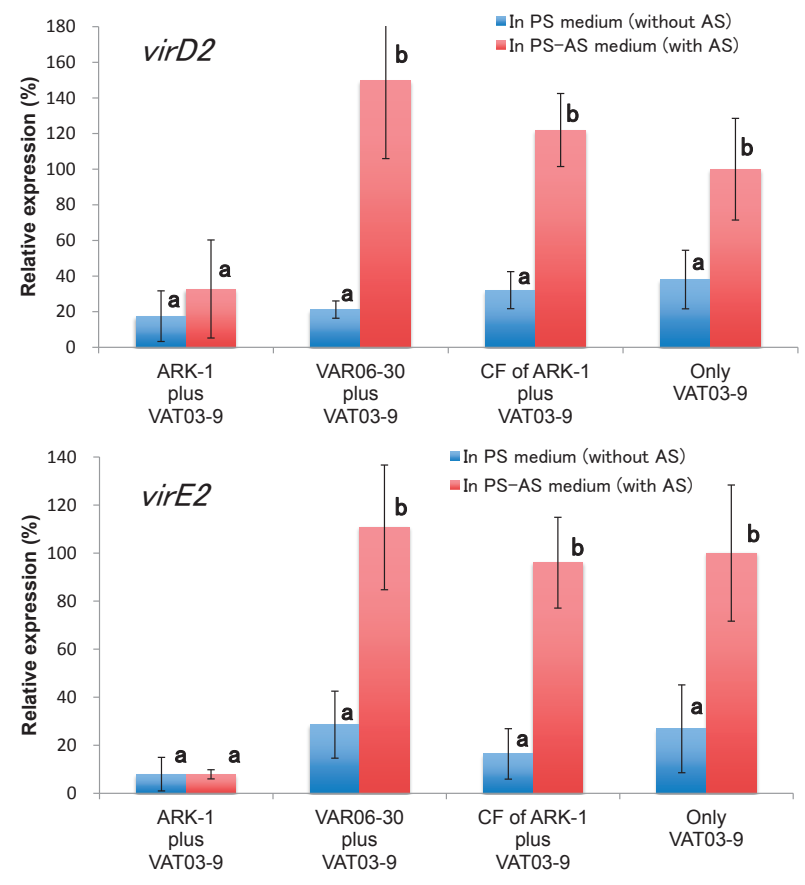

Fig. 10. Relative expression levels of the virD2 and virE2 genes in bacterial cells of the tumorigenic ( $\mathrm{Ti})$ R. vitis strain on potato sucrose (PS) medium and PS-AS medium, which also includes acetosyringone (AS), measured using reverse-transcription quantitative polymerase chain reaction (RT-qPCR). Values (\%) represent the relative expression levels of the vir genes at 1 day after inoculation (dai) compared with the value when only Ti strain VAT03-9 was inoculated ("only VAT03-9"), which had a value of $100 \%$. Data are means \pm standard deviation for samples corresponding to individual incubation flasks. Bars at a given date labeled with different letters differ significantly (Tukey's HSD test, $P<0.05$ ).

were prepared as described above. PS medium or PS-AS medium (PS medium with acetosyringone), was inoculated with one of the mixed suspensions or with a VAT03-9 cell suspension. Bacterial RNA was extracted after incubation, and RT-qPCR was performed for the detection of the virD2 and virE2 genes and relative quantification of the mRNA concentrations.

In the PS-AS medium, virD2 and virE2 expression levels in VAT03-9 cells were significantly reduced by co-incubation with ARK-1 (Fig. 10); however, the expression level was not significantly affected by co-incubation with VAR06-30 or CF of ARK-1. The levels of virD2 and virE2 expression induced by VAT03-9 incubated in the PS-AS medium were significantly higher than those in cells incubated in PS medium without acetosyringone (Fig. 10). In PS medium, virD2 and virE2 expression levels in VAT03-9 cells were not significantly affected by co-incubation with ARK-1, VAR06-30 or CF of ARK-1 (Fig. 10). These results suggested that the presence of ARK-1 can suppress virD2 and virE2 expression by the Ti strain in a culture medium that contains acetosyringone.

\section{Discussion}

Newly introduced nonpathogenic and antagonistic $R$. vitis strain ARK-1 is endophytic in grapevine and strongly inhibits tumor formation in grapevine. We also applied ARK-1 as a biological control of crown gall disease, and demonstrated that ARK-1 was able to control grapevine crown gall in field trials. Figure 11 shows our hypothesis of the mechanism of the effect of ARK-1 based on our research results until now. ARK-1 produced a zone of inhibition against tumorigenic Rhizobium spp. in in vitro assays; however, further examinations revealed that antibiosis was not the main mechanism of biological control. ARK-1 also reduced the pathogen population at the wound site; however, it seems that the suppression of virulence gene expressions is the key mechanism to reduce gall production. ${ }^{26)}$ Confirmation of suppression of two vir genes (virD2 and virE2) using the RT-qPCR was conducted in both in vitro and in planta experiments. The products of these genes, VirD2 and VirE2 proteins, are directly associated with the transformation of plant cells by $\mathrm{Ti}$ strains of Rhizobium, ${ }^{6), 7), 29)}$ resulting in gall formation. The suppression occurred prior to the reduction in the pathogen population. ${ }^{16), 17)}$ This mechanism is unique to ARK-1, because it is different from previously reported mechanisms of biological control of plant crown gall disease. Two known mechanisms of biological control of crown gall are antibacterial compounds produced by nonpathogenic strains $^{11), 13), 31), 32)}$ and a unique mechanism associated with the quorum-sensing and caseinolytic protease (clp) systems of nonpathogenic $R$. vitis strain F2/ 5.33) We will investigate whether ARK-1 could suppress the expression of vir genes other than virD2 and virE2 in grapevine in the near future.

The suppression of vir genes by ARK-1 occurred a few days after inoculation; however, the pathogenic population did not change until 7 dai. This result suggested that the suppression of vir gene expression probably inhibited the transformation of the host plant cells, thereby preventing the $\mathrm{Ti}$ strain from acquiring and catabolizing opines, which are amino acids produced as a result of transformation. Without the advantage of the opines as a food source, a growth of the Ti strain might suffer and result in a 


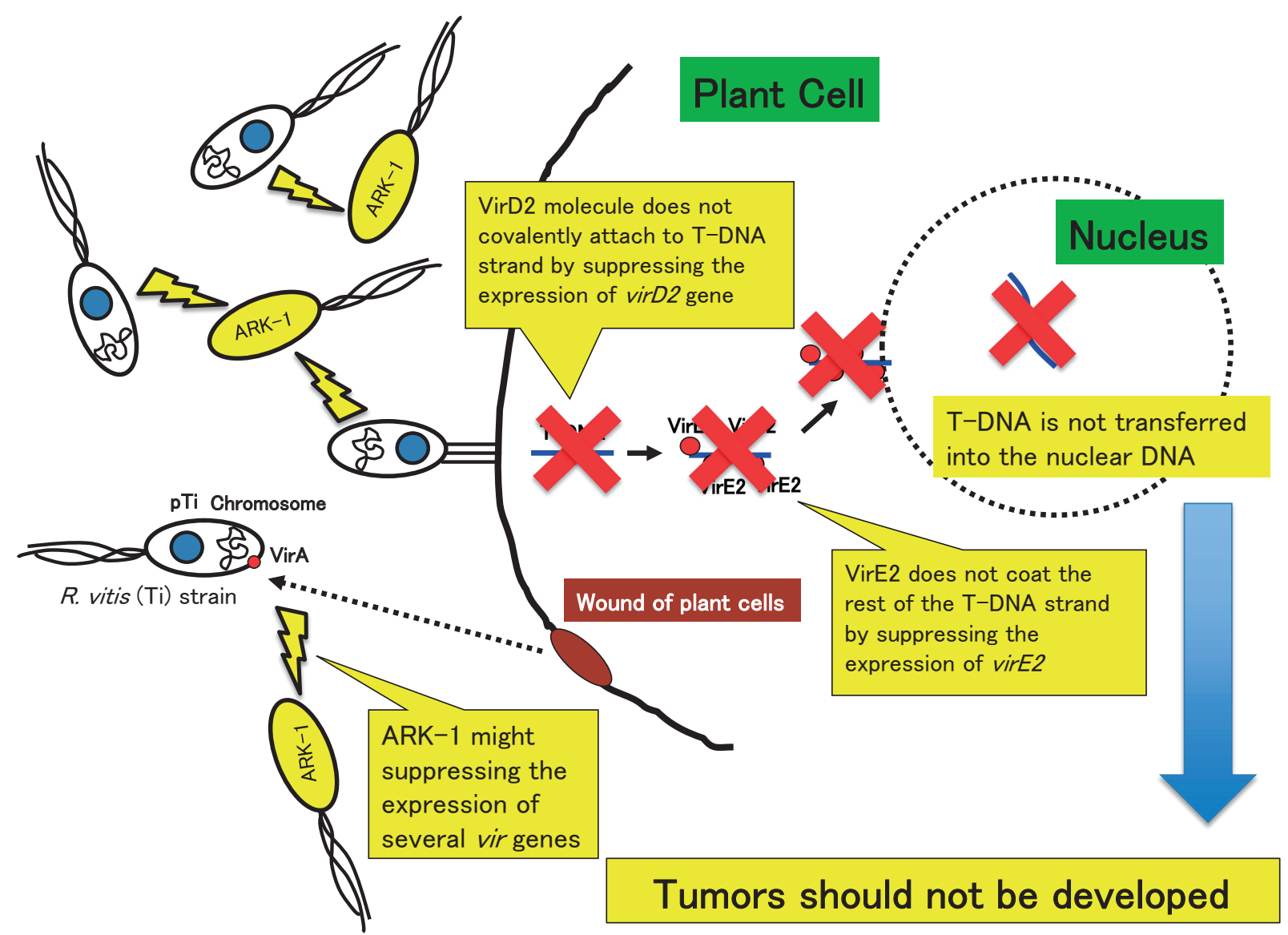

Fig. 11. The hypothesis of ARK-1's effect mechanism based on our research results until now. ARK-1 should suppress the expression of the virD2 and virE2 genes and then inhibit the pathway of T-DNA transfer into the plant nuclear DNA.

lower population than the ARK-1 population in grapevines. This hypothesis should be tested in future research.

In conclusion, ARK-1 suppressed the expression of the virulence genes of the Ti strain at the wound site and suppressed the development of crown gall disease via what appears to be a previously unreported mechanism. Even with these findings, several important questions remain to be addressed. More field validations of ARK-1 in different vineyard conditions in other countries around the world is necessary to verify the repeatability of biological control of crown gall by ARK-1 treatment. Testing in different environmental conditions will also aid our understanding of the mechanism of suppression provided by ARK-1. Our research projects may contribute to controlling crown gall in not only grapevines but also diverse crop species throughout the world in the near future. The ultimate goal in conducting this study is to evaluate strain ARK-1 as a biopesticide for the control crown gall disease. At present, we are developing a new biopesticide made from ARK-1 and getting positive results that the new biopesticide treatment is effective in controlling crown gall in grapevine and other plant species in field trials. We hope that a new biopesticide made from ARK-1 obtained from our studies will contribute to managing plant crown gall disease in agriculture around the world.

\section{Acknowledgments}

This work was supported by Grant-in-Aid for Scientific Research (KAKENHI) from the Japanese Society for the Promotion of Science (Grant No. 25850038 and $17 \mathrm{H} 03778)$. We express our sincere thanks to the following people for their useful comments: Drs. H. Nasu, H. Sawada, K. Kondo, Y. Ichinose, T. Shiraishi, M. Shimizu, K. Suzaki, and Y. Noutoshi. 


\section{References}

1) Kado, C.I. (2002) Crown gall. The Plant Health Instructor. doi: 10.1094/PHI-I-2002-1118-01.

2) Kawaguchi, A. (2012) Biological control for grapevine crown gall. In Grapevines: Varieties, Cultivation and Management (eds. Szabo, P.V. and Shojania, J.). Nova Science Publishers, New York, pp. 153-167.

3) Burr, T.J., Bazzi, C., Süle, S. and Otten, L. (1998) Crown gall of grape: biology of Agrobacterium vitis and the development of disease control strategies. Plant Dis. 82, 1288-1297.

4) Chilton, M.D., Drummond, M.H., Merlo, D.J., Sciaky, D., Montoya, A.L., Gordon, M.P. and Nester, E.W. (1977) Stable incorporation of plasmid DNA into higher plant cells: The moleculer basis of crown gall tumorigenesis. Cell 11, 263-271.

5) Zupan, J.R. and Zambryski, P. (1997) The Agrobacterium DNA transfer complex. Crit. Rev. Plant Sci. 16, 279-295.

6) Gelvin, S.B. (2012) Traversing the cell: Agrobacterium T-DNA's journey to the host genome. Front. Plant Sci. 3, 52. doi: 10.3389/fpls.2012.00052.

7) Nester, E.W. (2015) Agrobacterium: nature's genetic engineer. Front. Plant Sci. 5, 730. doi: 10.3389/ fpls.2014.00730.

8) Burr, T.J. and Katz, B.H. (1984) Grapevine cuttings as potential sites of survival and means of dissemination of Agrobacterium tumefaciens. Plant Dis. 68, 976-978.

9) Moore, L.W. and Warren, G. (1979) Agrobacterium radiobacter strain 84 and biological control of crown gall. Annu. Rev. Phytopathol. 17, 163-179.

10) Penyalver, R., Vicedo, B. and López, M.M. (2000) Use of the Genetically Engineered Agrobacterium Strain K1026 for Biological Control of Crown Gall. Eur. J. Plant Pathol. 106, 801-810.

11) Kerr, A. (1980) Biological control of crown gall through production of agrocin 84. Plant Dis. 64, $25-30$.

12) Reader, J.S., Ordoukhanian, P.T., Kim, J.G., de Crécy-Lagard, V., Hwang, I., Farrand, S. and Schimmel, P. (2005) Major biocontrol of plant tumors targets tRNA synthetase. Science $\mathbf{3 0 9}$ 1533.

13) Kawaguchi, A., Inoue, K. and Nasu, H. (2005) Inhibition of crown gall formation by Agrobacterium radiobacter biovar 3 strains isolated from grapevine. J. Gen. Plant Pathol. 71, 422-430.

14) Kawaguchi, A., Inoue, K. and Nasu, H. (2007) Biological control of grapevine crown gall by nonpathogenic Agrobacterium vitis strain VAR03-1. J. Gen. Plant Pathol. 73, 133-138.

15) Kawaguchi, A., Inoue, K. and Ichinose, Y. (2008) Biological control of crown gall of grapevine, rose, and tomato by nonpathogenic Agrobacterium vitis strain VAR03-1. Phytopathology 98, 1218-1225.

16) Kawaguchi, A. and Inoue, K. (2012) New antagonistic strains of non-pathogenic Agrobacterium vitis to control grapevine crown gall. J. Phytopathol.
160, 509-518.

17) Kawaguchi, A. (2013) Biological control of crown gall on grapevine and root colonization by nonpathogenic Rhizobium vitis strain ARK-1. Microbes Environ. 28, 306-311.

18) Kawaguchi, A., Inoue, K. and Tanina, K. (2015) Evaluation of the nonpathogenic Agrobacterium vitis strain ARK-1 for crown gall control in diverse plant species. Plant Dis. 99, 409-414.

19) Wolf, T.K., ed. (2008) Wine grape production guide for eastern North America. Natural Resource, Agriculture, and Engineering Service (NRAES) Cooperative Extension, Ithaca, N.Y.

20) Frank, Rimerman + Co. LLP (2017) The Economic Impact of Wine and Wine Grapes on the State of Virginia-2015. Frank, Rimerman + Co. LLP, St. Helena, CA.

21) Hayden, B.P. and Michaels, P.J. (2011) Virginia's climate. University of Virginia Climatology Office, VA.

22) Katori, M. (2011) Japan Wine Guide. Kohyusha, Tokyo, Japan.

23) Kawaguchi, A. (2011) Genetic diversity of Rhizobium vitis strains in Japan based on multilocus sequence analysis of $\operatorname{pyr} G$, recA and $r p o D$. J. Gen. Plant Pathol. 77, 299-303.

24) Rosenberg, M.S., Garrett, K.A., Su, Z. and Bowden, R.L. (2004) Meta-analysis in plant pathology: Synthesizing research results. Phytopathology 94, 1013-1017.

25) Kawaguchi, A., Kondo, K. and Inoue, K. (2012) Biological control of apple crown gall by nonpathogenic Rhizobium vitis strain VAR03-1. J. Gen. Plant Pathol. 78, 287-293.

26) Kawaguchi, A. (2014) Reduction in pathogen populations at grapevine wound sites is associated with the mechanism of biological control of crown gall by Rhizobium vitis strain ARK-1. Microbes Environ. 29, 296-302.

27) Kawaguchi, A. (2015) Biological control agent Agrobacterium vitis strain ARK-1 suppresses expression of the virD2 and virE2 genes in tumorigenic A. vitis. Eur. J. Plant Pathol. 143, 789-799.

28) Jones, H.D., Doherty, A. and Wu, H. (2005) Review of methodologies and a protocol for the Agrobacterium-mediated transformation of wheat. Plant Methods 1, 5-11.

29) Lacroix, B. and Citovsky, V. (2013) The roles of bacterial and host plant factors in Agrobacteriummediated genetic transformation. Int. J. Dev. Biol. 57, 467-481.

30) McCullen, C.A. and Binns, A.N. (2006) Agrobacterium tumefaciens and plant cell interactions and activities required for interkingdom macromolecular transfer. Annu. Rev. Cell Dev. Biol. 22, 101127.

31) Chen, F., Guo, Y.B., Wang, J.H., Li, J.Y. and Wang, H.M. (2007) Biological control of grape crown gall by Rahnella aquatilis HX2. Plant Dis. 91, 957-963.

32) Wang, H.M., Wang, H.X., Ng, T.B. and Li, J.Y. (2003) Purification and characterization of an antibacterial compound produced by Agrobacte- 
rium vitis strain $\mathrm{E} 26$ with activity against $A$. tumefaciens. Plant Pathol. 52, 134-143.

33) Kaewnum, S., Zheng, D., Reid, C.L., Johnson, K.L., Gee, J.C. and Burr, T.J. (2013) A host-specific biological control of grape crown gall by Agrobacterium vitis strain $\mathrm{F} 2 / 5$; its regulation and population dynamics. Phytopathology 103, 427435 .

(Received Mar. 23, 2017; accepted May 31, 2017)

\section{Profile}

Akira Kawaguchi was born in Okayama, Japan, in 1976. He graduated from the Faculty of Agricultural Science, Kyushu University in 2000. He was promoted to researcher in 2002 at the Agricultural Experimental Station, Okayama Agricultural General Center, and he obtained his Ph.D. in 2007 from Okayama University. He was promoted to senior researcher in 2009 at Agricultural Experimental Station, Okayama Agricultural General Center. He was posted in 2010 at Agricultural Research Institute, Okayama Prefectural Technology Centre for Agriculture, Forestry and Fisheries. He was promoted to chief in 2015 at the Department of Agriculture, Forestry and Fisheries, Okayama Prefectural Government. He was promoted to researcher at the Western Region Agricultural Research Center, National Agricultural and Food Research

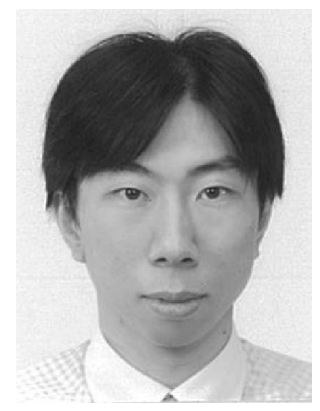
Organization (NARO). He has studied biological control using a new antagonistic microorganism to manage the soil-borne grapevine disease "crown gall", which occurs all over the world. His research achievements include the discovery of a new antagonistic bacterial strain named ARK-1, evaluation of the positive effect of ARK-1 to control crown gall on not only grapevine but also other plant species in field trials, population dynamics of ARK-1 in grapevine, some mechanisms of the effect of ARK-1, and so on. His final goal is to develop the new biopesticide to control crown gall and clarify the control mechanism of ARK-1 in the near future. For his achievements, he received 12th JSPS Prize and 12th Japan Academy Medal in 2016. 